\title{
Historical changes and inventory of macroalgae from Königshafen Bay in the northern Wadden Sea
}

\author{
D. Schories ${ }^{1,3}$, A. Albrecht ${ }^{2,3} \&$ H. Lotze $e^{2,4}$ \\ ${ }^{1}$ Centre for Tropical Marine Ecology; Fahrenheitstr. 1, 28359 Bremen, Germany \\ ${ }^{2}$ Dalhousie University, Biology Department; Halifax, N.S. B3H 4J1, Canada \\ ${ }^{3}$ Biologische Anstalt Helgoland; 25992 List/Sylt, Germany \\ ${ }^{4}$ Institut für Meereskunde; Düsternbrooker Weg 20, 24105 Kiel, Germany
}

Dedicated to P. Kornmann ( $\Psi$ ) and P.-H. Sahling

\begin{abstract}
Knowledge on the distribution, abundance and species richness of intertidal macroalgae occurring on sandy and muddy flats of the German Wadden Sea is still incomplete. We summarize published and unpublished information available on the presence of macroalgae on the tidal flats of Königshafen Bay (island of Sylt, North Sea), one of the more extensively studied areas of the Wadden Sea. A total of 46 green algal species, 36 brown algal species and 26 red algal species has been recorded within the last 120 years on soft and hard substrata of Königshafen Bay (disregarding species found unattached or drifting). Several of these species were only temporarily resident on the tidal flats. Today, at least 35 green, 15 brown and 12 red algal species occur within or close to Königshafen Bay. Significant long-term changes in species abundances have occurred in all three major groups of algae: Since the late 1970 s, dense green algal mats dominated by Enteromorpha flexuosa, E. radiata and E. prolifera have occurred regularly on the intertidal flats, whereas a general decrease of brown and red algae has been documented. Two red algal species, Gracilaria verrucosa and its epiphyte Callithamnion corymbosum, were conspicuous members of the macroflora until the middle of this century. Although still present in the 1980s, they have now disappeared completely. On the other hand, the brown alga Sargassum muticum has begun to colonize mussel beds. The causal background of long-term changes in the macroalgal flora of Königshafen Bay is discussed. Owing to substantial nomenclatural changes during the last 120 years, a revised species list with authors' names and synonyms is included.
\end{abstract}

\section{INTRODUCTION}

Towards the turn of last century, Reinke (1889a, b, 1892), Kuckuck (1897, 1900, 1902) and several other botanists (see Mollenhauer \& Lüning, 1988) investigated the algal flora of the German Baltic Sea and the island of Helgoland. They all showed comparatively little interest in the rare macroalgal vegetation of the intertidal mud-and sandflats of the Wadden Sea, an ecosystem which appeared as "a unique plantless desert continuing in the subtidal" (modified from Reinke, 1889c). Therefore, it is not suprising that the first information on Wadden Sea macroalgae was obtained as a mere byproduct of the North Sea Pommerania-expedition in 1872 (Magnus, 1874).

In contrast, the intertidal flats of Königshafen Bay are the only Wadden Sea areas in Germany where marine botanists have worked repeatedly, although not continually. Ac- 
cordingly, somewhat more detailed descriptions of the macroalgal vegetation and its changes over time are available from this region.

Magnus (1874) and Reinbold (1892) both spent only a few days in Königshafen Bay, giving incomplete accounts of the algal species present in the area. Kuckuck was the first marine botanist to undertake several excursions to the intertidal flats of the North Frisian Wadden Sea. Unfortunately, his collection of herbarium material and most of his unpublished botanical diaries were lost in the Second World War. Only a diary about the Wadden Sea, written between 1896 and 1903, still exists in the Department of Marine Botany of the Biologische Anstalt Helgoland (hereafter BAH). It contains the earliest detailed recordings of the algal vegetation at the island of Sylt with special emphasis on Königshafen Bay.

More than 20 years later, Nienburg (1927) investigated the upper eulittoral region of Königshafen. He concentrated on the development of the Enteromorpha-zone and the presence of Fucus vesiculosus f. mytili on mussel beds, but he did not produce a complete check-list of macroalgae. Except for Hagmeier's (1941) description of the macroflora associated with the North Frisian oyster beds, there were no botanical activities in Königshafen Bay after Nienburg until the 1950s.

As a consequence of the destruction of the BAH on Helgoland in the Second World War, the botanist Kornmann and his assistant Sahling worked on the island of Sylt from 1946 to 1958 where they studied the macroalgae of Königshafen Bay in detail. Although only a minor portion of this work was published by Kornmann at that time (1952), he made available to us many unpublished data. With the reconstruction of the BAH on Helgoland and the subsequent departure of Kornmann and Sahling from the island of Sylt, all botanical activities ended at once, so that there were no more detailed investigations of macroalgae in Königshafen Bay for several decades. In the late 1970s mass development of ephemeral green algae (Reise, 1983) indicated dramatic changes in the macrophytobenthos (Reise, 1994) and initiated recent phycological studies.

We reinvestigated the macrophytobenthos of Königshafen Bay with particular reference to historical changes. The species lists presented here summarize published and unpublished data. They are a preliminary approach towards an estimate of the macroalgal diversity of Königshafen Bay and adjacent Wadden Sea areas and the lists do not claim to be comprehensive. We offer information about the potential background for changes over time, as well as some details on the historical changes in single species' occurrences.

Ecological data on factors influencing abundance and distribution of green algae in Königshafen Bay are given by Schories \& Reise (1993), Lotze (1994) and Schories (1995 a, b), whereas Albrecht (1995) worked on macroalgal communities associated with mussel beds (Mytilus edulis).

\section{STUDY AREA}

Königshafen Bay is a shallow tidal bay at the northern tip of the island of Sylt (North Sea, Germany) (Fig. 1). The hydrography and macrofauna of the area have been described by Wohlenberg (1937), Reise (1985) and Reise et al. (1994a). Historical changes in the biological structural entities (e.g. mussel beds, seagrass meadows and green algal mats) have been summarized by Reise et al. (1989). A sedimentological study of the area was 


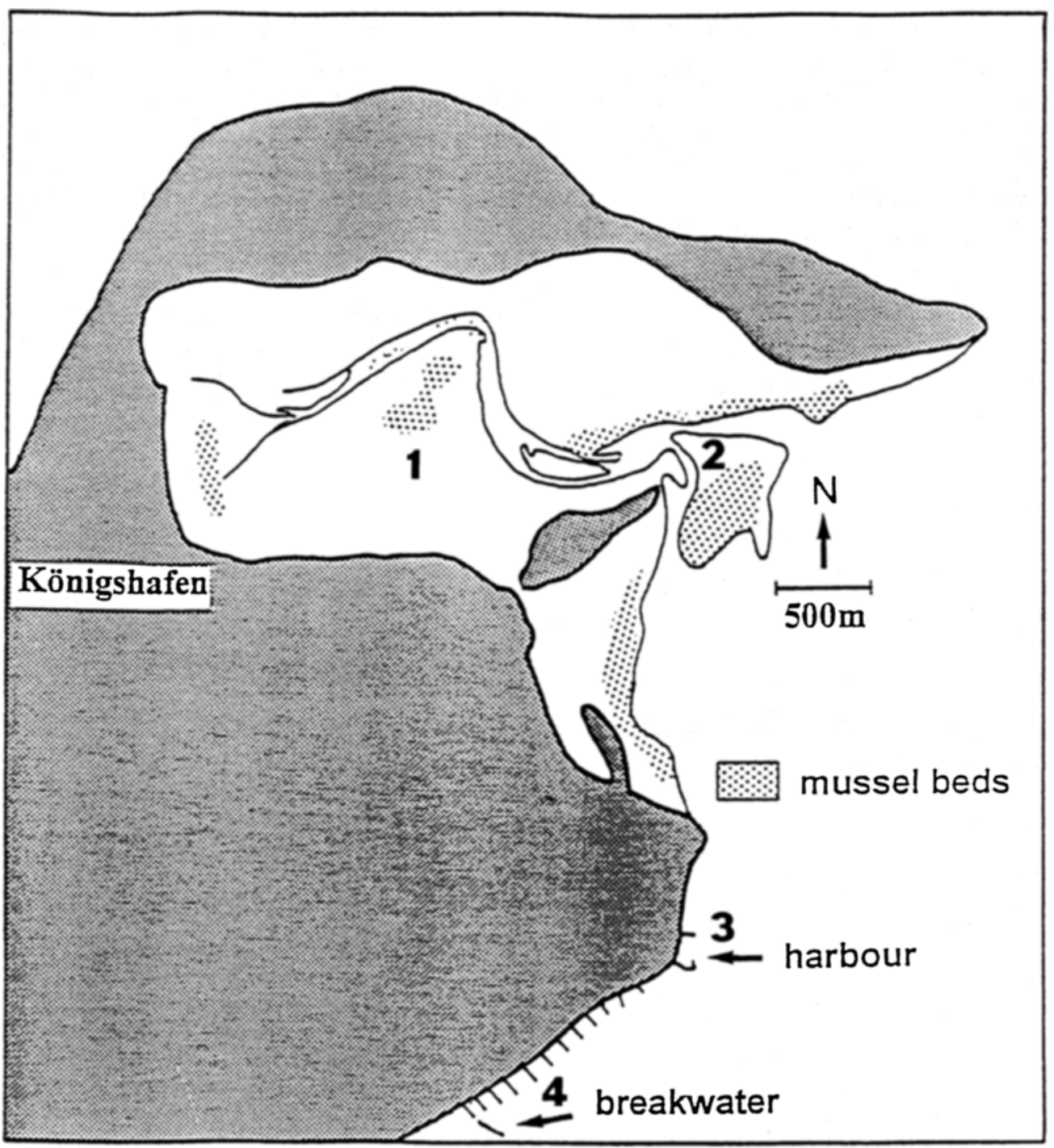

Fig. 1. Diagram of the Wadden Sea area near the island of Sylt as found at present, showing inner Königshafen Bay (1), outer Königshafen Bay (2), List harbour (3) and a stony breakwater, south of the village of List (4)

carried out by Austen (1992). The aeolic input of dune-sands from the west and the formation of a sand spit system in the south of the bay have caused substantial morphological changes of Königshafen Bay through to the present (Bayerl \& Higelke, 1994). Austen (1994) showed that surface sediments have changed over the last 50 years, resulting in an areal decline in mudflats and an increasing consolidation of the mud in the period up to 1981. 


\section{MATERIALS, METHODS AND NOMENCLATURE}

Since the binomials of many species have been subject to major changes, a revised list of the species with authors' names and synonyms from the reference material is included (Table 1). In most cases, it was not possible to countercheck the taxonomic information given in the older literature because of missing herbarium material. This might have led to some errors in genera as Cladophora or Enteromorpha, in which detailed

Table 1. List of species with authors, and synonyms. - Within this century, many changes have been made to the Latin binomials. This is a revised species list with authors' names and synonyms used in the cited literature (see Table 2) and in the unpublished data material. The names are arranged alphabetically within the classes: Rhodophyceae, Fucophyceae (Phaeophyceae) and Chlorophyceae, with the valid names printed in bold italic letters and synonyms in italics. For more detailed information about further synonyms used in earlier literature see Nielsen et al. (1995) and Pankow

$(1971,1990)$

\section{RHODOPHYCEAE}

Acrochaetium secundatum (Lyngb.) Dixon

Antithamnion plumula

Bangia atropurpurea (Roth) C. A. Ag.

Bangia fuscopurpurea

Callithamnion corymbosum (Smith in

Ceramium nodulosum (Lightf.) Ducluz.

Ceramium rubrum

Chantransia daviesii

Chantransia secundata

Chantransia thuretii

Chondrus crispus Stackh.

Colaconema daviesii (Dillw.) Stegenga

Colaconema nemalionis (De Not. ex Dufour)

Dumontia contorta (Gmel.) Rupr.

\section{Dumontia filiformis}

Dumontia incrassata

Erythrotrichia carnea (Dillw.)

Erythrotrichia ceramicola

Erythrotrichia reflexa (C

Goniotrichum elegans

Gracilaria confervoides

Gracilaria verrucosa (Huds.) Papenf.

Hildenbrandia prototypus

Hildenbrandia rubra (Sommerf.) Menegh.

Hildenbrandia rosea

Lithothamnion sonderi Hauck

Melobesia lejolisii

Melobesia membranacea Lamour. non Esper

Nemalion multifidum (Weber \& Mohr) Endl.
Chantransia secundata (Lyngb.) Thuret in Le Jolis

see Pterothamnion plumula

Bangia fuscopurpurea (Dillw.) Lyngb.

see Bangia atropurpurea

t.) Lyngb.

Ceramium rubrum (Huds.) C. A. Ag.

see Ceramium nodulosum

see Colaconema daviesii

see Acrochetium secundatum

see Colaconema nemalionis

Chantransia daviesii (Dillw.) Thuret

Chantransia thuretii (Bornet) Kylin

Dumontia filiformis (O. F. Müller in Flor. dan.)

Grev.

Dumontia incrassata (O. F. Müller in Flor. dan.)

Lamour.

see Dumontia contorta

see Dumontia contorta

Erythrotrichia ceramicola (Lyngb.) Aresch.

see Erythrotrichia carnea

oni sensu Rosenv.

see Stylonema alsidii

see Gracilaria verrucosa

Gracilaria confervoides (L.) Grev.

see Hildenbrandia rubra

Hildenbrandia rosea Kütz.

Hildenbrandia prototypus Nardo

see Hildenbrandia rubra

see Pneophyllum lejolisii 
$\begin{array}{ll}\text { Pneophyllum lejolisii (Rosanoff) Chamberlain } & \text { Melobesia lejolisii Rosanoff } \\ \text { Polysiphonia atrorubescens } & \text { see Polysiphonia nigra }\end{array}$

Polysiphonia elongata (Huds.) Sprengel Polysiphonia fibrillosa (Dillw.) Sprengel Polysiphonia fucoides (Huds.) Grev. Polysiphonia nigra (Huds.) Batters Polysiphonia nigrescens Polysiphonia stricta (Dillw.) Grev. Polysiphonia urceolata Polysiphonia violacea Porphyra laciniata Porphyra umbilicalis (L.) Kütz.

Pterothamnion plumula (Ellis) Näg. in Näg. et Cramer

Polysiphonia violacea (Roth) Grev. in Hooker Polysiphonia nigrescens (Huds.) Griff. ex Harv. Polysiphonia atrorubescens (Dillw.) Grev. see Polysiphonia fucoides Polysiphonia urceolata (Lightf. ex Dillw.) Grev. see Polysiphonia stricta see Polysiphonia fibrillosa see Porphyra umbilicalis Porphyra laciniata (Lightf. 1792) J. G. Ag. 1882/83

Antithamnion plumula (Ellis) Thuret in Le Jolis

Rhodomela confervoides (Huds.) Silva

Rhodomela subfusca Rhodomela subfusca (Woodw.) C. A. Ag. see Rhodomela confervoides

Stylonema alsidii (Zanard.) Drew

\section{FUCOPHYCEAE (PHAEOPHYCEAE)}

Acinetospora crinita (Carm. ex Harvey) Kornmann

Ascocyclus orbicularis

Botrytella micromora Bory

Chorda filum (L.) Stackh.

Chordaria flagelliformis (O. F. Müller in Flor dan.) C. A. Ag.

Desmotrichum balticum Kütz.

Desmotrichum undulatum see Punctaria tenuissima

Dictyosiphon foeniculaceus (Huds.) Grev.

Dictyota dichotoma (Huds.) Lamour.

Dumontia filiformis

Ectocarpus confervoides

Ectocarpus dasycarpus

Ectocarpus fuscatus

Ectocarpus granulosus

Ectocarpus sandrianus

Ectocarpus siliculosus (Dillw.) Lyngb.

Ectocarpus tomentosus

Elachista fucicola (Velley) Aresch.

Fucus mytili

Fucus platycarpus

Fucus spiralis L. var. platycarpus (Thur.) Batt.

see Dictyosiphon chordaria

see Ectocarpus siliculosus

see Ectocarpus siliculosus

see Hincksia ovata

see Hincksia granulosa

see Hincksia sandriana

Ectocarpus confervoides (Roth) Kjellm.

Ectocarpus dasycarpus Kuckuck

see Spongonema tomentosum

see Fucus vesiculosus f. mytili see Fucus spiralis var, platycarpus

Fucus vesiculosus L. f. mytili (Nienburg) Nienhuis

Fucus vesiculosus $\mathrm{L}$.

Hincksia granulosa (Smith) Silva

Hincksia ovata (Kjellm.) Silva

Hincksia sandriana (Zanard.) Silva

Laminaria digitata (Huds.) Lamour.
Ectocarpus granulosus (Smith) C. A. Ag. Ectocarpus fuscatus Zanard. ex Menegh. Ectocarpus sandrianus Zanard. 
Table 1 (Continued)

\section{Laminaria saccharina (L.) Lamour. \\ Leathesia difformis (L.) Aresch. \\ Leptonema fasciculatum \\ Leptonematella fasciculata (Reinke) Silva \\ Mesogloia divaricata \\ Microsyphar porphyrae Kuckuck}

Myrionema magnusii (Sauv.) Lois.

Myrionema strangulans Carm. mscr. in Grev.

Myrionema vulgare

Myriotrichia clavaeformis Harv.

Myriotrichia repens

Petalonia fascia (Müller in Flor. dan.) Kuntze

Petalonia zosterifolia (Reinke) Hamel

Phyllitis fascia

Phyllitis zosterifolia

Pilayella litoralis (L.) Kjellm.

Punctaria latifolia Grev.

Punctaria plantaginea (Roth) Grev.

Punctaria tenuissima (J. G. Ag.) Grev.

Ralfsia verrucosa (Aresch.) J. G. Ag.

Sargassum muticum (Yendo) Fensholt

Scytosiphon lomentaria (Lyngb.) Endl.

Sorocarpus uvaeformis

Sphacelaria cirrosa (Roth) C. A. Ag.

Sphaerotrichia divaricata (C. A. Ag.) Kylin

Spongonema tomentosus (Huds.) Kütz.

Stictyosiphon sp.

Ulonema rhizophorum (Foslie) Sauvag. see Leptonematella fasciculata

Leptonema fasciculatum Reinke

see Sphaerotrichia divaricata

Ascocyclus orbicularis (J. G. Ag.) De Toni

Myrionema vulgare Thuret in Le Jolis

see Myrionema strangulans

Myriotrichia repens Hauck

see Myriotrichia clavaeformis

Phyllitis fascia (Müller in Flor, dan.) Kütz.

Phyllitis zosterifolia (Reinke) Kuntze

see Petalonia fascia

see Petalonia zosterifolia

Desmotrichum undulatum (J. G. Ag.) Reinke

see Botrytella micromora

Mesogloia divaricata (C. A. Ag.) Kütz.

Ectocarpus tomentosus (Huds.) Lyngb.

\section{CHLOROPHYCEAE}

Acrochaete repens Pringsh.

Acrochaete wittrockii (Wille) Nielsen

Blidingia marginata (J. G. Ag.) Dang. Blidingia minima (Nägeli ex Kütz.) Kylin

Bryopsis hypnoides

Bryopsis plumosa (Huds.) C. A. Ag.

Capsosiphon fulvescens (C. A. Ag.) Setch. et Gardner

Chaetomorpha aerea (Gooden ex Dillw.) Kütz.

Chaetomorpha linum (O. F. Müller in Flor. dan.) Kütz.

Chaetomorpha sutoria (Berk.) Kornmann

Cladophora glaucescens

Cladophora flexuosa

see Cladophora sericea

see Cladophora sericea

Cladophora fracta (O. F. Müller ex Vahl in Flor. dan.) Kütz.

Cladophora hirta see Cladophora sericea

Cladophora hutchinsiae (Dillw.) Kütz.

Cladophora lanosa

Cladophora lehmaniana (Lindenberg) Kütz. see Spongomorpha aeruginosa

Cladophora sericea (Huds.) Kütz. sensu van den Hoek

Cladophora glaucescens (Giff. ex. Harv.) Harv. 
Table 1 (Continued)

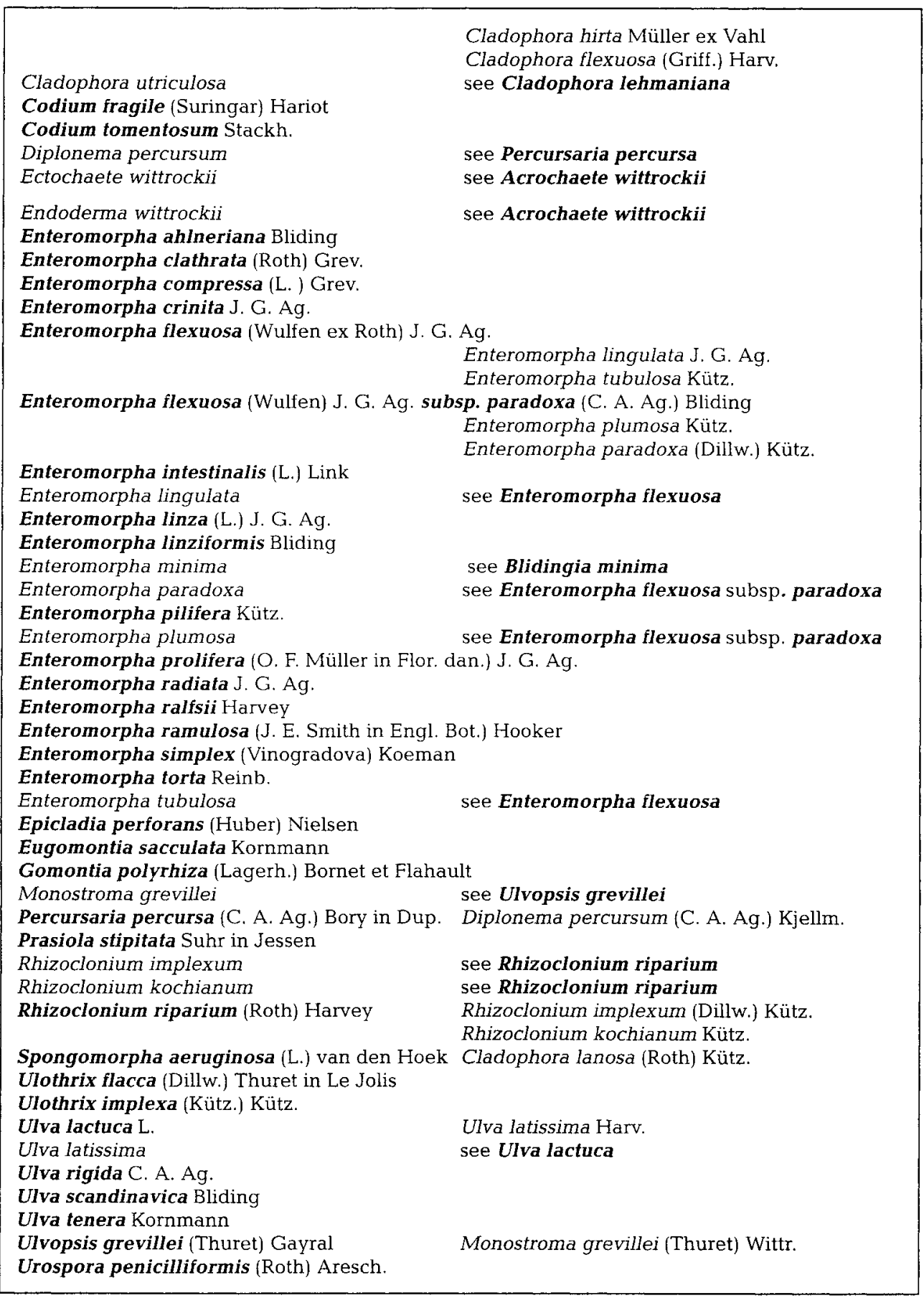


taxonomic studies were first carried out in the 1960s (Bliding,1963; Söderström, 1963; van den Hoek, 1963). Abundant herbarium material and slides exist from the period 1946 to 1958, when Kornmann and Sahling worked at the Wadden Sea Station of the BAH. Macroalgae which were encountered only as drifting specimens are not considered here. Data sources, both published literature and unpublished data integrated in this study, are given in Table 2 a.

Our own investigations, carried out between 1990 and 1995, were largely restricted to Königshafen Bay, although all available information from adjacent areas has been added to the check-list. SCUBA diving was used to determine the lower depth limit of the macroalgal vegetation growing on artificial hard substrata in direct vicinity of Königshafen Bay (i.e. on the walls of List harbour).

\section{RESULTS}

\section{Historical changes}

A total of 46 green algal species, 36 brown algal species and 26 red algal species has been recorded on the soft and hard substrata of Königshafen Bay or in adjacent areas over the last 120 years (Table 2 b). However, several of these species have been detected only infrequently on the tidal flats. For example, there are only single recordings of Dictyota dichotoma and Codium tomentosum (Hagmeier, 1941).

Table 2 a. Literature and unpublished data used for the survey, and explanations of the symbols

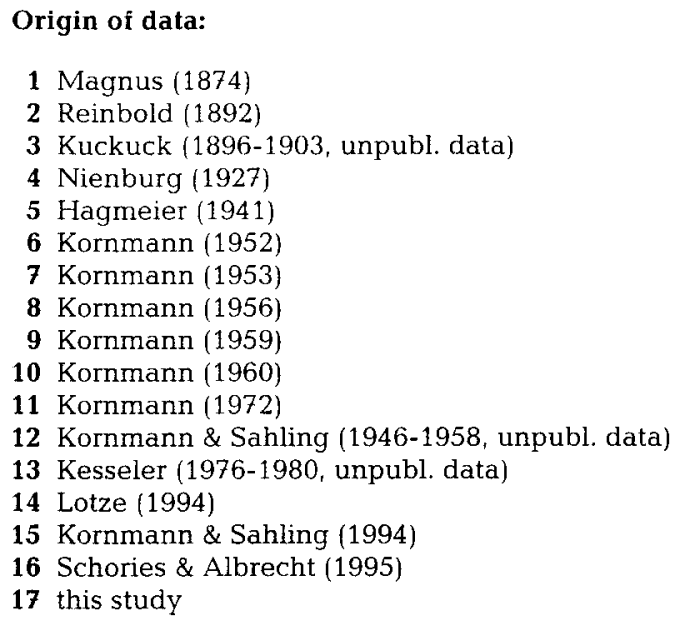

\section{Symbols:}

K Königshafen Bay

O Oyster beds around the island of Sylt

A Intertidal and low subtidal areas in the surroundings of Königshafen Bay (including anthropogenic hard substrata such as dikes and walls)

B Beach region of the village of List 
Table $2 \mathrm{~b}$. Check-list of multicellular benthic macroalgae settling in Königshafen Bay or in adjacent tidal areas during the last 120 years. Due to taxonomic difficulties individuals were not always determined to species level; therefore, individuals marked as "sp" or as "spp" do not necessarily represent additions to the listed members of the same genus. The taxonomic classification of the Ulva-, the Enteromorpha- and the Cladophora-group is uncertain in all data material before 1990. The Porphyra-group was revised by Kornmann \& Sahling (1992), but this could not be taken into consideration in this table. Recently M. Steentoft (unpubl.) separated individuals of Gracilaria ver. rucosa (Huds.) Papenf. found in Königshafen Bay by Kornmann \& Sahling [No. 12 in Table 2 a] and Kesseler [No. 13] into the species Gracilaria gracilis (Stackh.) Steentoft, L. Irvine \& Farnham and Gracilariopsis longissima (S. G. Gmelin) Steentoft, L. Irvine \& Farnham (see Steentoft et al. [1995] for detailed information). However, we maintain the name Gracilaria verrucosa (Huds.) Papenf. in this study.

\begin{tabular}{|c|c|c|c|c|}
\hline & $1872-1927$ & $1932-1958$ & $1976-1980$ & $1990-1994$ \\
\hline \multicolumn{5}{|l|}{ RHODOPHYCEAE } \\
\hline Acrochaetium secundatum & $3 \mathrm{~K}$ & $6 \mathrm{~A}$ & - & - \\
\hline Bangia atropurpurea & $3 \mathrm{~A}$ & $6 \mathrm{~A}$ & - & - \\
\hline Callithamnion corymbosum & $3 \mathrm{~K}$ & $6 \mathrm{~K}_{i} 12 \mathrm{~A}, \mathrm{~K}$ & $13 \mathrm{~K}$ & - \\
\hline Ceramium nodulosum & $1 \mathrm{~B} ; 3 \mathrm{~A}, \mathrm{~K} ; 4 \mathrm{~K}$ & $5 \mathrm{O} ; 6 \mathrm{~K} ; 7 \mathrm{~A} ; 12 \mathrm{~A}, \mathrm{~K}$ & $13 \mathrm{~A}, \mathrm{~K}$ & $17 \mathrm{~A}, \mathrm{~K}$ \\
\hline Chondrus crispus & $3 \mathrm{~A}$ & $6 \mathrm{~K}_{i} 12 \mathrm{~A}, \mathrm{~K}$ & $13 \mathrm{~K}$ & $17 \mathrm{~A}, \mathrm{~K}$ \\
\hline Colaconema sp. & $3 \mathrm{~A}$ & - & $6 \mathrm{~A}$ & - \\
\hline Colaconema daviesii & - & $12 \mathrm{~A}$ & - & $17 \mathrm{~K}$ \\
\hline Colaconema nemalionis & - & $12 \mathrm{~K}$ & - & - \\
\hline Dumontia contorta & $3 \mathrm{~A}, \mathrm{~K}$ & $6 \mathrm{~K} ; 12 \mathrm{~A}, \mathrm{~K}$ & $13 \mathrm{~K}$ & $17 \mathrm{~A}, \mathrm{~K}$ \\
\hline Erythrotrichia carnea & $1 \mathrm{~B}$ & $6 \mathrm{~A}, \mathrm{~K}_{i} 12 \mathrm{~A}, \mathrm{~K}$ & - & $17 \mathrm{~K}$ \\
\hline Erythrotrichia reflexa & - & $12 \mathrm{~K}$ & - & $17 \mathrm{~K}$ \\
\hline Gracilaria verrucosa & $1 \mathrm{~B} ; 3 \mathrm{~K}$ & $5 \mathrm{O} ; 6 \mathrm{~K} ; 12 \mathrm{~A}, \mathrm{~K}$ & $13 \mathrm{~K}$ & - \\
\hline Hildenbrandia rubra & $1 \mathrm{~B} ; 3 \mathrm{~A}$ & $12 \mathrm{~K}$ & - & - \\
\hline Lithothamnion sp. & - & $50,6 \mathrm{~K}$ & & \\
\hline Lithothamnion sonderi & $3 \mathrm{~A}$ & $12 \mathrm{~A}, \mathrm{~K}$ & - & - \\
\hline Melobesia membranacea & $1 \mathrm{~B}$ & - & - & - \\
\hline Nemalion multifidum & $3 \mathrm{~A}$ & $6 \mathrm{~A}_{i} 12 \mathrm{~A}$ & - & - \\
\hline Pneophyllum lejolisii & $4 \mathrm{~K}$ & & & \\
\hline Polysiphonia elongata & $2 \mathrm{~A} ; 3 \mathrm{~A}, \mathrm{~K}$ & $5 \mathrm{O} ; 6 \mathrm{~K} ; 7 \mathrm{~A}_{i} 12 \mathrm{~A}, \mathrm{~K}$ & $13 \mathrm{~K}$ & $7 \mathrm{~A}, \mathrm{~K}$ \\
\hline Polysiphonia fibrillosa & $3 \mathrm{~A}, \mathrm{~K} ; 4 \mathrm{~K}$ & $6 \mathrm{~A} ; 12 \mathrm{~A}, \mathrm{~K}$ & $13 \mathrm{~K}$ & $17 \mathrm{~K}$ \\
\hline Polysiphonia fucoides & $1 \mathrm{~B} ; 3 \mathrm{~A}, \mathrm{~K}$ & $5 \mathrm{O} ; 6 \mathrm{~A}, \mathrm{~K} ; 7 \mathrm{~A} ; 12 \mathrm{~A}, \mathrm{~K}$ & $13 \mathrm{~A}, \mathrm{~K}$ & $17 \mathrm{~A}, \mathrm{~K}$ \\
\hline Polysiphonia nigra & $3 \mathrm{~K}_{\mathrm{i}} 4 \mathrm{~K}$ & $6 \mathrm{~A}, \mathrm{~K} ; 7 \mathrm{~A} ; 12 \mathrm{~A}, \mathrm{~K}$ & $13 \mathrm{~K}$ & - \\
\hline Polysiphonia stricta & $4 \mathrm{~K}$ & $6 \mathrm{~A}$ & - & - \\
\hline Porphyra spp. & - & $12 \mathrm{~A}, \mathrm{~K}$ & $13 \mathrm{~A}, \mathrm{~K}$ & $17 \mathrm{~A}, \mathrm{~K}$ \\
\hline Porphyra umbilicalis & $3 \mathrm{~K}$ & $6 \mathrm{~A}, \mathrm{~K} ; 12 \mathrm{~A}, \mathrm{~K}$ & & $17 \mathrm{~A}, \mathrm{~K}$ \\
\hline Pterothamnion plumula & - & - & $13 \mathrm{~K}$ & - \\
\hline Rhodomela confervoides & $3 \mathrm{~A}, \mathrm{~K}$ & - & - & - \\
\hline Stylonema alsidii & $3 \mathrm{~A}$ & $6 \mathrm{~K} ; 12 \mathrm{~A}, \mathrm{~K}$ & - & $17 \mathrm{~K}$ \\
\hline \multicolumn{5}{|c|}{ FUCOPHYCEAE (PHAEOPHYCEAE) } \\
\hline Acinetospora crinita & - & $7 \mathrm{~A} ; 12 \mathrm{~K}$ & - & - \\
\hline Botrytella micromora & - & $12 \mathrm{~A}$ & - & - \\
\hline Chorda filum & $1 \mathrm{~B} ; 3 \mathrm{~A}$ & $5 \mathrm{O} ; 6 \mathrm{~A} ; 12 \mathrm{~A}, \mathrm{~K}$ & - & $17 \mathrm{~K}$ \\
\hline Chordaria flagelliformis & $3 \mathrm{~A}$ & $6 \mathrm{~A}$ & - & - \\
\hline Desmotrichum balticum & - & $6 \mathrm{~A}_{\mathrm{i}} 12 \mathrm{~K}$ & - & - \\
\hline Dictyosiphon foeniculaceus & $3 \mathrm{~A}$ & - & - & - \\
\hline Dictyota dichotoma & - & 50 & - & - \\
\hline Ectocarpus siliculosus & $3 \mathrm{~A}, \mathrm{~K} ; 4 \mathrm{~K}$ & $6 \mathrm{~A} ; 7 \mathrm{~A} ; 12 \mathrm{~A}, \mathrm{~K}$ & $13 \mathrm{~K}$ & $17 \mathrm{~A}, \mathrm{~K}$ \\
\hline
\end{tabular}


Table $2 \mathrm{~b}$ (Continued)

\begin{tabular}{|c|c|c|c|c|}
\hline & $1872-1927$ & $1932-1958$ & $1976-1980$ & $1990-1994$ \\
\hline Elachista fucicola & $3 \mathrm{~K}$ & $6 \mathrm{~K} ; 12 \mathrm{~A}, \mathrm{~K}$ & $13 \mathrm{~K}$ & $17 \mathrm{~A}, \mathrm{~K}$ \\
\hline \multicolumn{2}{|c|}{ Fucus spiralis var. platycarpus - } & $6 \mathrm{~A} ; 12 \mathrm{~A}$ & - & $17 \mathrm{~A}, \mathrm{~K}$ \\
\hline Fucus vesiculosus f. mytili & $4 \mathrm{~K}$ & $5 \mathrm{O} ; 6 \mathrm{~K} ; 12 \mathrm{~A}, \mathrm{~K}$ & $13 \mathrm{~K}$ & $17 \mathrm{~A}, \mathrm{~K}$ \\
\hline Fucus vesiculosus & $1 \mathrm{~B} ; 3 \mathrm{~A}, \mathrm{~K}, 4 \mathrm{~K}$ & $6 \mathrm{~A} ; 12 \mathrm{~A}$ & - & $17 \mathrm{~A}, \mathrm{~K}$ \\
\hline Hincksia granulosa & - & $6 \mathrm{~A} ; 7 \mathrm{~A} ; 12 \mathrm{~A}, \mathrm{~K}$ & $13 \mathrm{~K}$ & $17 \mathrm{~K}$ \\
\hline Hincksia ovata & - & $12 \mathrm{~K}$ & - & - \\
\hline Hincksia sandriana & - & $12 \mathrm{~A}, \mathrm{~K}$ & - & - \\
\hline Laminaria digitata & - & $12 \mathrm{~A}$ & - & - \\
\hline Laminaria saccharina & - & $6 \mathrm{~A} ; 12 \mathrm{~A}$ & $13 \mathrm{~A}$ & $17 \mathrm{~A}$ \\
\hline Leathesia difformis & $3 \mathrm{~K}$ & - & - & - \\
\hline Leptonematella fasciculata & - & $12 \mathrm{~K}$ & - & - \\
\hline Microsyphar porphyrae & $3 \mathrm{~K}$ & $6 \mathrm{~K}_{\mathrm{i}} 12 \mathrm{~K}$ & - & - \\
\hline Myrionema magnusii & $3 \mathrm{~K}$ & - & - & - \\
\hline Myrionema strangulans & $3 \mathrm{~A}, \mathrm{~K}$ & $6 \mathrm{~K} ; 12 \mathrm{~A}, \mathrm{~K}$ & - & $17 \mathrm{~K}$ \\
\hline Myriotrichia clavaeformis & - & $6 \mathrm{~A}_{;} 12 \mathrm{~A}, \mathrm{~K}$ & - & - \\
\hline Petalonia fascia & $3 \mathrm{~A}$ & $6 \mathrm{~A} ; 12 \mathrm{~A}, \mathrm{~K}$ & $13 \mathrm{~A}, \mathrm{~K}$ & $17 \mathrm{~A}, \mathrm{~K}$ \\
\hline Petalonia zosterifolia & $3 \mathrm{~A}$ & - & - & - \\
\hline Pilayella litoralis & $3 \mathrm{~A}, \mathrm{~K}$ & $6 \mathrm{~A}_{;} 12 \mathrm{~A}, \mathrm{~K}$ & - & $17 \mathrm{~A}, \mathrm{~K}$ \\
\hline Punctaria latifolia & - & $6 \mathrm{~A}$ & - & - \\
\hline Punctaria plantaginea & - & $12 \mathrm{~K}$ & & $17 \mathrm{~A}$ \\
\hline Punctaria tenuissima & - & $12 \mathrm{~K}$ & - & - \\
\hline Ralfsia verrucosa & $3 \mathrm{~K}$ & $6 \mathrm{~K} ; 12 \mathrm{~A}, \mathrm{~K}$ & - & $17 \mathrm{~A}, \mathrm{~K}$ \\
\hline Sargassum muticum & - & - & - & $\begin{array}{l}16 \mathrm{~A}, \mathrm{~K} ; 17 \\
\mathrm{~A}, \mathrm{~K}\end{array}$ \\
\hline Scytosiphon lomentaria & $3 \mathrm{~A}, \mathrm{~K}$ & $6 \mathrm{~A}, \mathrm{~K} ; 12 \mathrm{~A}, \mathrm{~K}$ & $13 \mathrm{~K}$ & $17 \mathrm{~A}, \mathrm{~K}$ \\
\hline Sphacelaria cirrosa & $2 \mathrm{~A}, 3 \mathrm{~K}$ & - & - & - \\
\hline Sphaerotrichia divaricata & - & $12 \mathrm{~K}$ & - & - \\
\hline Spongonema tomentosus & - & $12 \mathrm{~K}$ & - & - \\
\hline Stictyosiphon sp. & - & $12 \mathrm{~K}$ & - & - \\
\hline Ulonema rhizophorum & - & $12 \mathrm{~K}$ & - & - \\
\hline \multicolumn{5}{|l|}{ CHLOROPHYCEAE } \\
\hline Acrochaete repens & - & $12 \mathrm{~K}$ & - & - \\
\hline Acrochaete wittrockii & - & $12 \mathrm{~K}$ & - & - \\
\hline Blidingia marginata & - & - & - & $17 \mathrm{~K}$ \\
\hline Blidingia minima & - & $6 \mathrm{~A}, 12 \mathrm{~A}$ & - & $17 \mathrm{~K}$ \\
\hline Bryopsis plumosa & - & $6 \mathrm{~A}, 12 \mathrm{~A}, \mathrm{~K}$ & $13 \mathrm{~A}, \mathrm{~K}$ & $17 \mathrm{~A}, \mathrm{~K}$ \\
\hline Capsosiphon fulvescens & - & $6 \mathrm{~A}, 12 \mathrm{~K}$ & - & - \\
\hline Chaetomorpha aerea & - & $5 \mathrm{O} ; 6 \mathrm{~K}, 12 \mathrm{~A}, \mathrm{~K}$ & - & $17 \mathrm{~A}, \mathrm{~K}$ \\
\hline Chaetomorpha linum & $2 \mathrm{~A}_{i} 3 \mathrm{~K}, 4 \mathrm{~K}$ & $6 \mathrm{~K}, 7 \mathrm{~A}_{i} 12 \mathrm{~A}, \mathrm{~K}$ & $13 \mathrm{~A}, \mathrm{~K}$ & $17 \mathrm{~A}, \mathrm{~K}$ \\
\hline Chaetomorpha sutoria & - & $11 \mathrm{~K}$ & $13 \mathrm{~K}$ & $17 \mathrm{~K}$ \\
\hline Cladophora spp. & $3 \mathrm{~A}$ & - & $13 \mathrm{~A}, \mathrm{~K}$ & $17 \mathrm{~A}, \mathrm{~K}$ \\
\hline Cladophora fracta & - & $12 \mathrm{~A}$ & - & - \\
\hline Cladophora hutchinsiae & - & $6 \mathrm{~A}, 12 \mathrm{~K}$ & $13 \mathrm{~K}$ & - \\
\hline Cladophora lehmaniana & - & $12 \mathrm{~A}$ & - & - \\
\hline Cladophora sericea & $2 \mathrm{~A} ; 3 \mathrm{~K}$ & $5 \mathrm{O} ; 6 \mathrm{~A} ; 12 \mathrm{~A}, \mathrm{~K}$ & $13 \mathrm{~K}$ & $17 \mathrm{~A}, \mathrm{~K}$ \\
\hline Codium fragile & - & - & $13 \mathrm{~K}$ & $17 \mathrm{~A}$ \\
\hline Codium tomentosum & - & 50 & - & - \\
\hline Enteromorpha spp. & - & - & $13 \mathrm{~A}, \mathrm{~K}$ & $17 \mathrm{~A}, \mathrm{~K}$ \\
\hline
\end{tabular}


Table 2 b (Continued)

\begin{tabular}{|c|c|c|c|c|}
\hline & $1872-1927$ & $1932-1958$ & $1976-198$ & 1990-1994 \\
\hline Enteromorpha ahlneriana & - & - & - & $17 \mathrm{~K}$ \\
\hline Enteromorpha clathrata & $3 \mathrm{~K}, 4 \mathrm{~K}$ & $12 \mathrm{~A}, \mathrm{~K}$ & - & $14 \mathrm{~K} ; 17 \mathrm{~A}, \mathrm{~K}$ \\
\hline Enteromorpha compressa & $3 \mathrm{~A}$ & $5 \mathrm{O} ; 6 \mathrm{~K} ; 12 \mathrm{~A}, \mathrm{~K}$ & $13 \mathrm{~K}$ & $14 \mathrm{~K}_{i} 17 \mathrm{~A}_{1} \mathrm{~K}$ \\
\hline Enteromorpha crinita & $4 \mathrm{~K}$ & $12 \mathrm{~A}, \mathrm{~K}$ & - & - \\
\hline Enteromorpha flexuosa & - & $6 \mathrm{~A} ; 12 \mathrm{~A}, \mathrm{~K}$ & - & $14 \mathrm{~K}_{\mathrm{i}} 17 \mathrm{~A}, \mathrm{~K}$ \\
\hline $\begin{array}{l}\text { Enteromorpha flexuosa } \\
\text { subsp. paradoxa }\end{array}$ & $3 \mathrm{~K}_{i} 4 \mathrm{~K}$ & - & - & - \\
\hline Enteromorpha intestinalis & - & $6 \mathrm{~K}_{i} 12 \mathrm{~A}, \mathrm{~K}$ & - & $14 \mathrm{~K}_{\mathrm{i}} 17 \mathrm{~A}, \mathrm{~K}$ \\
\hline Enteromorpha linza & $3 \mathrm{~A}, 4 \mathrm{~K}$ & $5 \mathrm{O} ; 6 \mathrm{~A} ; 12 \mathrm{~A}, \mathrm{~K}$ & $13 \mathrm{~A}$ & $14 \mathrm{~K}_{i} 17 \mathrm{~A}, \mathrm{~K}$ \\
\hline Enteromorpha linziformis & - & - & - & $14 \mathrm{~K} ; 17 \mathrm{~K}$ \\
\hline Enteromorpha pilifera & - & - & - & $14 \mathrm{~K} ; 17 \mathrm{~K}$ \\
\hline Enteromorpha prolifera & - & - & - & $14 \mathrm{~K} ; 17 \mathrm{~K}$ \\
\hline Enteromorpha radiata & - & - & - & $14 \mathrm{~K} ; 17 \mathrm{~A}, \mathrm{~K}$ \\
\hline Enteromorpha ralfsii & - & - & - & $14 \mathrm{~K}_{i} 17 \mathrm{~K}$ \\
\hline Enteromorpha ramulosa & $4 \mathrm{~K}$ & - & - & - \\
\hline Enteromorpha simplex & - & - & - & $14 \mathrm{~K}_{i} 17 \mathrm{~A}, \mathrm{~K}$ \\
\hline Enteromorpha torta & - & $6 \mathrm{~K} ; 7 \mathrm{~A} ; 12 \mathrm{~K} ; 8 \mathrm{~K}$ & - & $14 \mathrm{~K} ; 17 \mathrm{~A}, \mathrm{~K}$ \\
\hline Epicladia perforans & - & - & - & $17 \mathrm{~K}$ \\
\hline Gomontia polyrhiza & $2 \mathrm{~A}$ & - & $9 \mathrm{~K}$ & - \\
\hline Eungomontia sacculata & - & $10 \mathrm{~K}$ & - & $17 \mathrm{~A}, \mathrm{~K}$ \\
\hline Percursaria percursa & - & $\begin{array}{l}6 \mathrm{~K} ; 7 \mathrm{~A} ; 12 \mathrm{~A}, \mathrm{~K} \\
8 \mathrm{~A}, \mathrm{~K}\end{array}$ & - & $17 \mathrm{~K}$ \\
\hline Prasiola stipitata & - & - & - & $17 \mathrm{~K}$ \\
\hline Rhizoclonium riparium & $4 \mathrm{~K}$ & $7 \mathrm{~A} ; 12 \mathrm{~A}, \mathrm{~K}$ & - & $17 \mathrm{~K}$ \\
\hline Spongomorpha aeruginosa & - & $6 \mathrm{~A}$ & - & - \\
\hline Ulothrix flacca & $3 \mathrm{~A}$ & $6 \mathrm{~A} ; 12 \mathrm{~A}, \mathrm{~K}$ & - & $17 \mathrm{~K}$ \\
\hline Ulothrix implexa & - & $7 \mathrm{~A}_{i} 6 \mathrm{~A}_{i} 12 \mathrm{~A}_{1} \mathrm{~K}$ & - & $17 \mathrm{~K}$ \\
\hline Ulva lactuca & $2 \mathrm{~A}_{i} 4 \mathrm{~K}$ & $6 \mathrm{~A} ; 12 \mathrm{~A}, \mathrm{~K}$ & $13 \mathrm{~A}, \mathrm{~K}$ & $14 \mathrm{~K}, 17 \mathrm{~A}, \mathrm{~K}$ \\
\hline Ulva rigida & - & - & - & $14 \mathrm{~K} ; 17 \mathrm{~K}$ \\
\hline Ulva scandinavica & - & - & - & $14 \mathrm{~K}, 17 \mathrm{~K}$ \\
\hline Ulva tenera & - & $15 \mathrm{~K}$ & - & - \\
\hline Ulvopsis grevillei & - & $6 \mathrm{~A} ; 12 \mathrm{~A}, \mathrm{~K}$ & $13 \mathrm{~A}, \mathrm{~K}$ & $17 \mathrm{~A}, \mathrm{~K}$ \\
\hline Urospora penicilliformis & - & $6 \mathrm{~A}_{i} 12 \mathrm{~A}$ & - & $17 \mathrm{~K}$ \\
\hline
\end{tabular}

From the often selective emphasis of workers on certain groups of algae, it is not feasible to assess the relative abundance of single species which are listed in Table $2 \mathrm{~b}$. Neither does the fragmentary and infrequent information represent a comprehensive and useful basis for estimating absolute abundance of each species over time. Nevertheless, the benthic macroflora recorded in the period between 1870 and 1946 differs in two major respects from that which occurs at present:

(A) Before the late 1970s, dense green algal mats were not mentioned in any of the references to Königshafen Bay (see Table 2 a), although the genus Enteromorpha, which is at present the most important contributor to the algal mats (Fig. 2), was already a conspicuous member of the macrophytobenthos (Nienburg, 1927). 


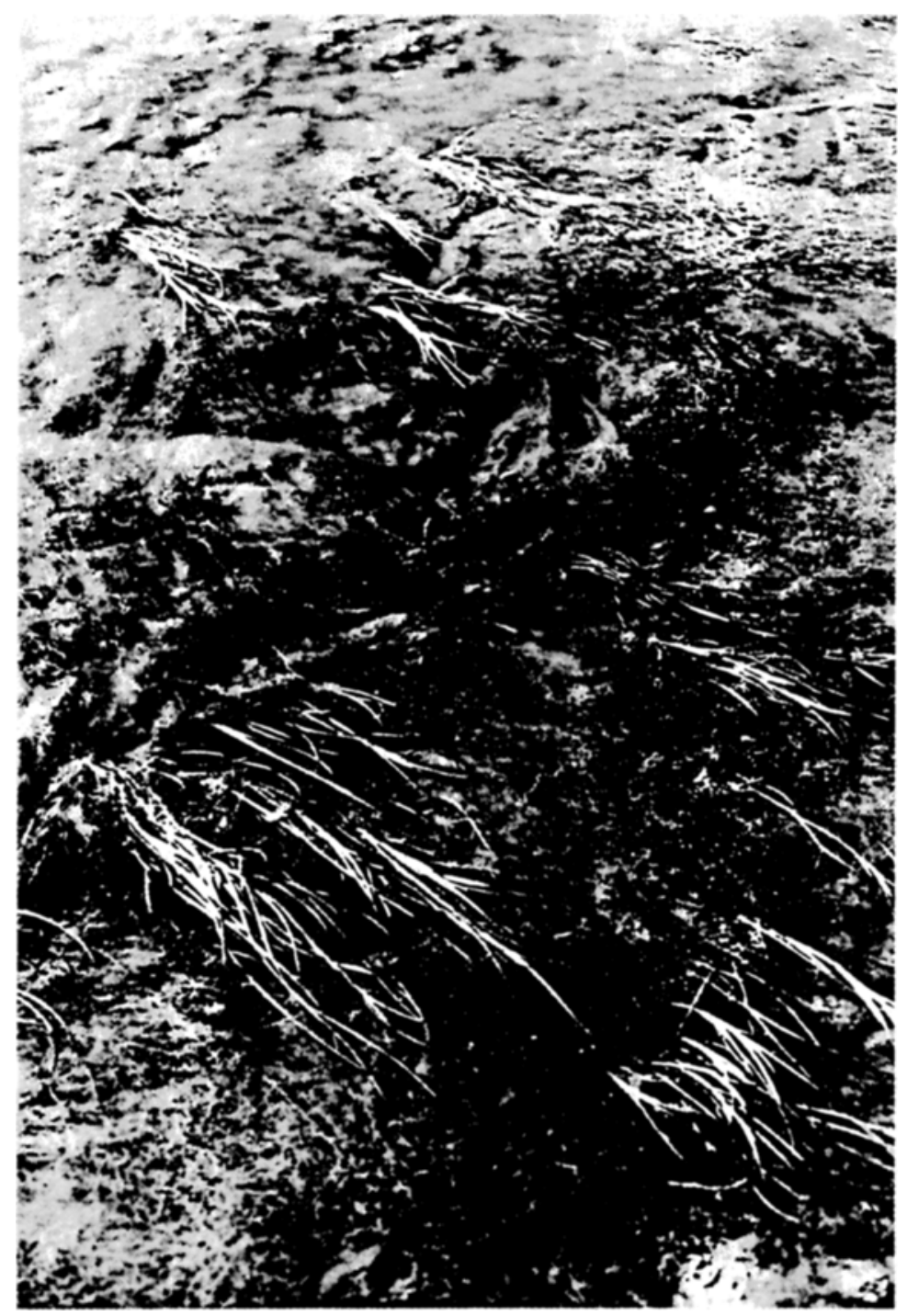

Fig. 2. A dense Enteromorpha spp. mat covering a bed of Zostera marina in the western part of Königshafen Bay in 1992

(B) Our measurements at the List harbour walls show a maximum vegetation depth of $3 \mathrm{~m}$ below mean high water level (MHWL). Only crustose forms of brown algae (e.g. Ralfsia verrucosa) were found in greater depths, on mobile biogenic substrata such as shells of hermit crabs (Eupagurus bernhardus), but not on firm substrata. In the earlier part of the century the lower vegetation depth limit must have been several metres below that of the present vegetation as Hagmeier (1941) reported the growth of macroalgae on subtidal oysterbeds down to ca $8 \mathrm{~m}$. 
Currently, at least 12 red algal species, 13 brown algal species and 34 green algal species are present in Königshafen Bay. The green alga Codium fragile and the brown algae Laminaria saccharina and Punctaria plantaginea were found only outside Königshafen. In relation to the findings of Kornmann (1952) and Kornmann \& Sahling (1946-1958, unpublished data) in Königshafen, the number of red algal species has decreased from 16 to 12 , and brown algal species from 23 to 12 . The abundance of green algal species increased from 23 to 34 . The latter is related to high numbers of species in the two genera Enteromorpha and Ulva which were mainly found on sand-and mudflats in our survey.

The complete disappearance of the red algae Gracilaria verrucosa and its epiphyte Callithamnion corymbosum is particularly interesting. Both species, first mentioned by Magnus (1874), were still conspicuous members of the macroflora of the outer part of Königshafen Bay in the 1950s, but became rare in the 1980s. Also, Polysiphonia nigra, Hildenbrandia rubra and Lithothamnion sonderi have not been found in the recent survey. The two crustose species never occurred very frequently in Königshafen, whereas Polysiphonia nigra was regularly present in the outer part of the bay, growing attached to mussel shells and pebbles.

\section{Present situation}

Three Enteromorpha species were regularly represented in the algal mats of Königshafen Bay (E. flexuosa, E. prolifera, E. radiata). E. ralfsii was only of local importance in the north east of Königshafen, where it grew attached to tubes of the polychaete Lanice conchilega. E. clathrata and E. torta were found commonly, though often with low biomass. Chaetomorpha sutoria was scarce on the tidal flats in Königshafen in 1990 and between 1992 and 1994, but formed mats measuring up to $20 \mathrm{~cm}$ deep in 1991 (Fig. 3). We very rarely found juveniles of Chaetomorpha and Cladophora in Königshafen Bay, whereas juvenile stages of Enteromorpha occurred in high abundances (hundreds $\mathrm{m}^{-2}$ ) attached to mudsnail shells in spring (Schories \& Reise, 1993; Schories, 1995 a, b). Ulva spp., on the other hand, are transported by currents into the bay from other areas as adults and continue to grow without reproducing in protected localities. Thus, we recorded a maximum length of ca $3 \mathrm{~m}$ for a single plant of Ulva scandinavica in 1992. Direct development of Ulva germlings into adult plants is very rare in Königshafen Bay.

On mussel beds, the bladder wrack Fucus vesiculosus f. mytili is the most conspicuous macroalga. Additionally, extensive growth of the red alga Dumontia contorta and the brown alga Petalonia fascia can be observed in spring in depressions of individual mussel beds. In summer months, large individual plants of Porphyra spp. may grow up to $50 \mathrm{~cm}$ in length when grazing pressure is low. The red sheets cover parts of some mussel bed surfaces completely. This blanketing was observed under natural conditions in the outer part of Königshafen Bay in 1993, and in grazer exclusion experiments carried out in 1993 and 1994 by Albrecht (1995).

The occurrence of the invasive Japanese brown alga Sargassum muticum is a new phenomenon in Königshafen Bay (Schories \& Albrecht, 1995). In this location S. muticum grows attached to mussel beds (Mytilus edulis), and this represents the first record for attachment to a biogenic hard substratum in the Frisian Wadden Sea. Prior to this, unattached specimens had been found for several years following storm events along the beaches of the island of Sylt. In March 1993, S. muticum was discovered attached to the substratum almost simultaneously in two locations: on mussel beds in the outer part of 


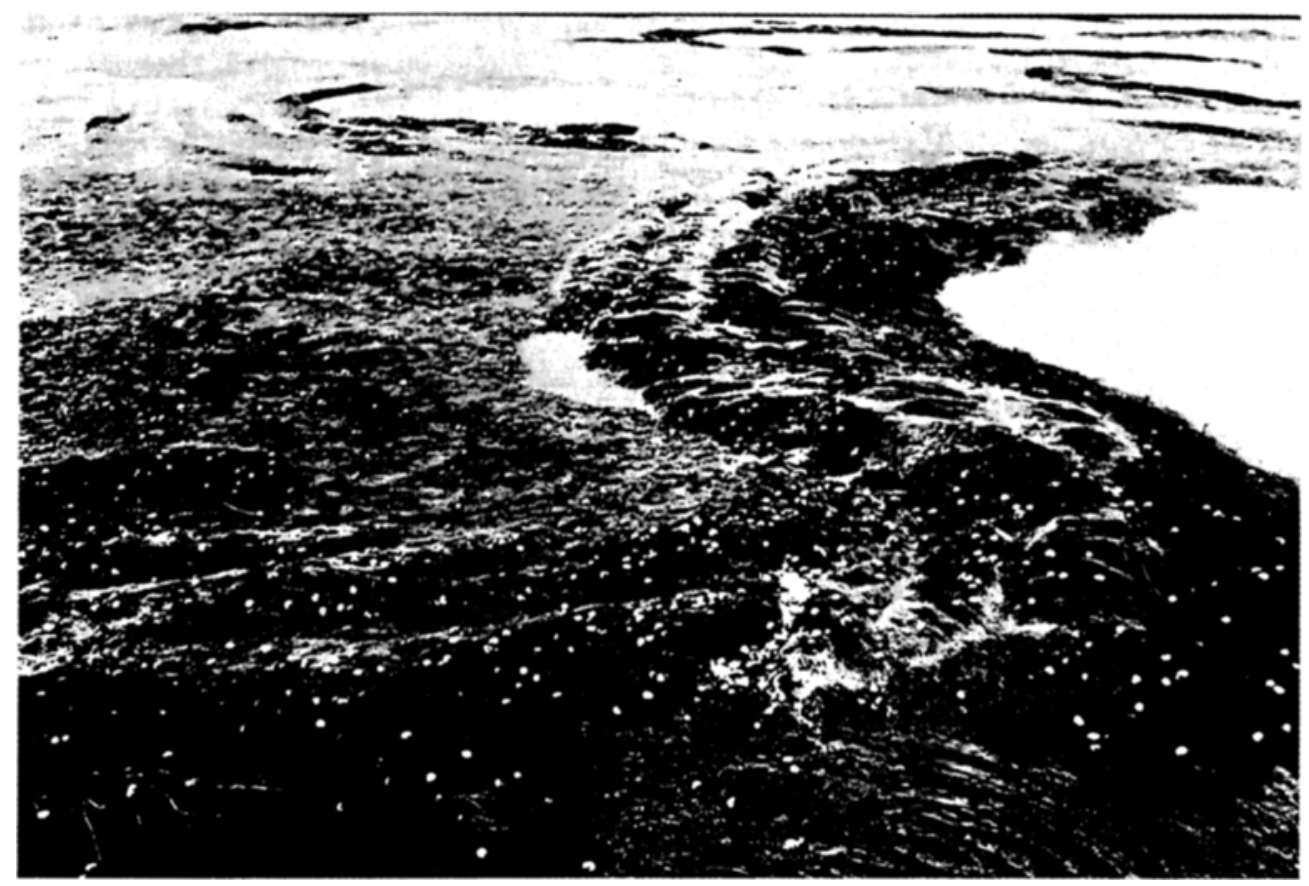

Fig. 3. Chaetomorpha sutoria growing in mats in the western part of Königshafen Bay in 1991.

Littorinid snails (Littorina littorea) were abundant in decaying parts of the algal mats(below)

Königshafen Bay close to the subtidal zone and outside the bay in the low subtidal zone on a breakwater south of the village of List. During summer, the plants grow to a length of up to $2 \mathrm{~m}$ before degeneration processes lead to thallus losses in autumn (Fig. 4). At present, $S$. muticum is still part of the macroflora in these two areas.

Another invasive species recorded for the first time in the vicinity of Königshafen Bay is the green alga Codium fragile. It occurs regularly on the breakwater where $S$. muticum was found.

\section{DISCUSSION}

The macrophytobenthos of Königshafen Bay has undergone a change more dramatic than that reflected in our check-list (Table 2). Since the beginning of the century, two opposing trends are evident. Some red and brown algal species have become rare or have disappeared completely from the intertidal zone (e.g. Callithamnion corymbosum, Gracilaria verrucosa, Hildenbrandia rubra). In contrast, the abundances and biomasses of several green algal genera (Chaetomorpha, Cladophora, Enteromorpha and Ulva) have exhibited massive increases in the upper eulittoral zone. The presence in the intertidal zone of species such as Ceramium nodulosum, Polysiphonia elongata, P. fucoides and Porphyra spp. seems not to have changed in the long term.

When trying to explain these historical developments, it is important to realize that environmental conditions which influence the occurrence of wild organisms have changed through both natural and anthropogenic effects. It has become obvious that human 


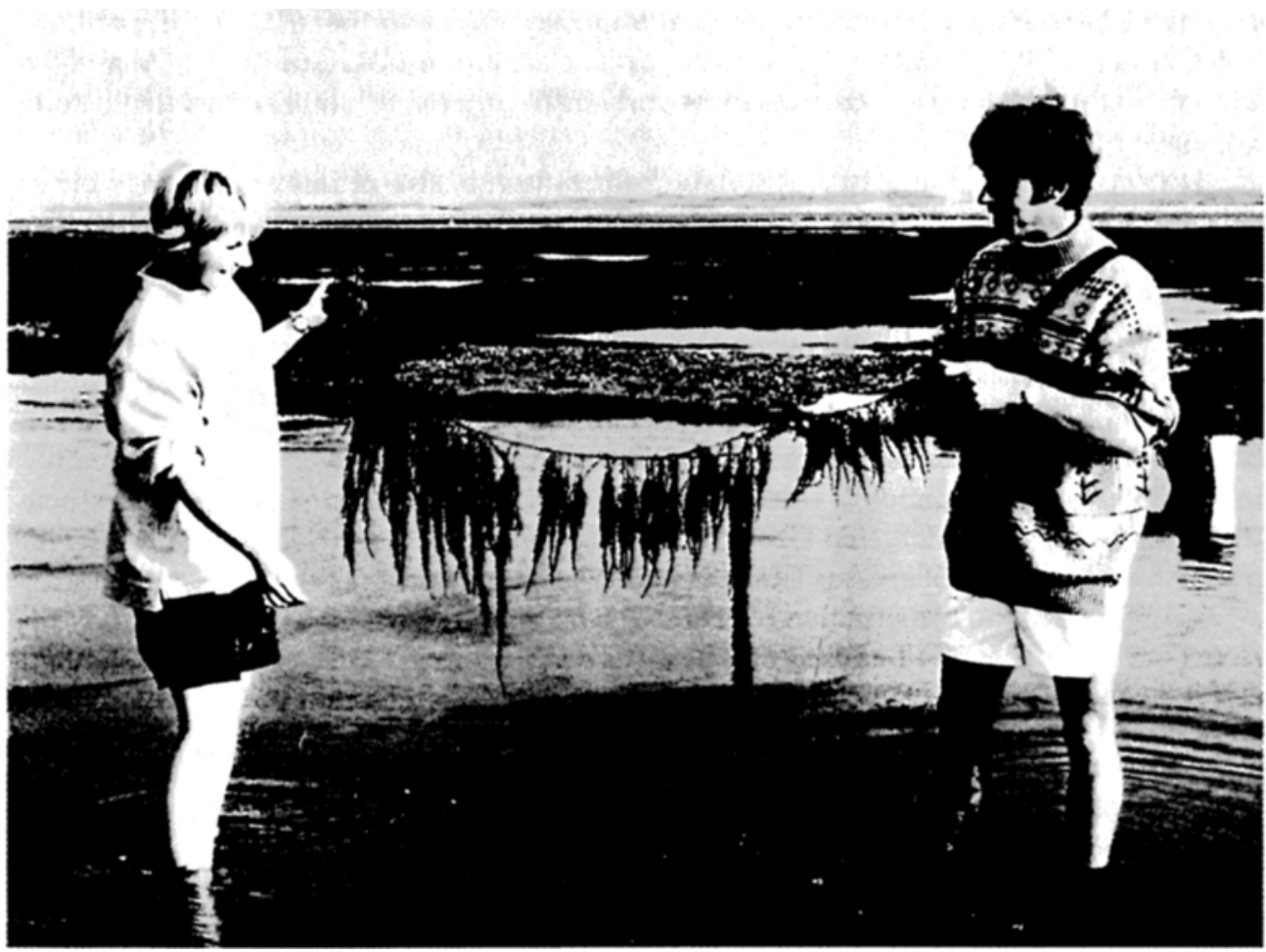

Fig. 4. Specimen of Sargassum muticum found attached to mussel beds between two tidal inlets in the outer part of Königshafen Bay; July, 1994

impact is of great significance for often dramatic changes in the environment (Agger, 1989), particularly in an ecosystem such as the Wadden Sea which has been structured by human activity for a thousand years. However, in Königshafen Bay natural fluctuations of environmental parameters interact with anthropogenic changes and are at least partly responsible for the observed changes. Therefore, natural as well as human-induced aspects of different factors affecting macroalgal growth will be discussed together.

\section{Substratum availability}

During the late 1980s, De Jonge \& Peletier (1992) found a dense cover of Ulva spp. in the western Dutch Wadden Sea, apparently related to the presence of hard substrata supplied by blue mussel cultures (Mytilus edulis). After $M$. edulis became rare, because of insufficient spatfall, Ulva became unimportant in the western Dutch Wadden Sea. In this case, the availability of a hard substratum seems to have been the limiting factor for the development of Ulva. On the other hand, mussel beds have always been present in Königshafen Bay in this century (Nienburg, 1927; Wohlenberg, 1937), but they have also shown high fluctuations in terms of abundance and spatial distribution (Reise et al., 1989). In contrast to the observations of De Jonge \& Peletier (1992) in the Netherlands, the 
growth of Ulva on mussel beds in Königshafen Bay has never been of any importance. High biomass of Ulva only occurs when plants drift into the bay and begin vegetative growth, so that this species' abundance is probably regulated by other factors in our study area (see below).

However, the availability of a suitable substratum is also of relevance to the occurrence of epiphytic macroalgae: seagrass, which was abundant throughout the Wadden Sea, decreased dramatically in the 1930s. Almost the entire population of Zostera marina, growing at, or just below, the low water mark was affected in the Dutch (den Hartog, 1994) as well as in the German Wadden Sea. Wohlenberg (1935) reported a strong disease-related decline of Zostera in a subtidal bed east of Königshafen Bay during 1933-34 (for further information see Reise et al., 1989). This bed disappeared completely. The loss of seagrass beds in the Dutch and German Wadden Sea more than 60 years ago is thought to have altered the abundance of macroalgae, especially of the red algal epiphytes associated with them. The work of van Goor (1921) on the Dutch Wadden Sea gives a lasting impression of the potential species richness of macroalgae in seagrass beds.

Additionally, the construction of artificial hard substratum - in Königshafen Bay this refers particularly to the building of a new dike in the early 1930 s - might have enhanced the growth of some species which had previously been limited in their distribution by lack of suitable attachment surfaces. In particular, the high eulittoral species Blidingia minima, B. marginata and Prasiola stipitata have been found recently growing on the dike, thus contributing to the increase in green algal species compared to earlier investigations.

\section{Grazing}

Not all substrata serving as potential attachment surfaces are colonized by macraoalgae otherwise abundant in the area. This is often attributable to grazing effects.

Geertz-Hansen et al. (1993) showed that, in a eutrophic Danish estuary, the development of nuisance macroalgae like Ulva lactuca can be controlled by grazing isopods (Idotea sp.). Albrecht (1995) demonstrated the influence of littorinid snails on the presence of several macroalgal species on mussel beds in Königshafen Bay. Experiments using exclusion cages to reduce Littorina littorea densities showed that, within a short time in summer, opportunistic species such as Porphyra spp., Ulva lactuca and Enteromorpha spp. developed on the mussel shells. Therefore, changes in abundance of ephemeral green and red algae might often have been related to grazing pressure in Königshafen Bay. Unfortunately, no simultaneous investigations of grazers and macroalgae were carried out in the bay before 1992 (Wilhelmsen \& Reise, 1994; Albrecht, 1995)

\section{Eutrophication}

Eutrophication has been the predominant factor of change over the last 50 years. Proceeding from the estuaries, enhanced nitrogen and phosphorus loads have increased the nutrient concentrations in intertidal waters of the North Frisian Wadden Sea during winter (Martens, 1989 a, b, 1992; Hickel et al, 1993). Several authors (cf. Buttermoore, 1977; Montgomery \& Soulsby, 1981; Kolbe et al., 1994; Reise \& Siebert, 1994) assumed a positive correlation between eutrophication and green algal biomass. Thus, there are many regions in the world where mass development of Ulva to nuisance proportions is strongly 
exacerbated by high nutrient inputs into the system (Sawyer, 1965; Sfriso et al, 1987; Piriou \& Menesguen, 1992).

Although more and more global records substantiate these positive correlations, the evidence for a direct link is by no means conclusive. In our view, the general relationship between the potential for green algal mass development and the environmental parameters involved is often too complex to be demonstrated in single case studies. Grazing pressure (Geertz-Hansen et al., 1993; Wilhelmsen \& Reise, 1994), availability of substrata and anchorage (Schories \& Reise, 1993), rainfall (Piriou \& Menesguen, 1992), desiccation (Townsend \& Lawson, 1972), competition between macroalgae, microphytobenthos and phytoplankton (Fong et al., 1993) are only a few examples indicating the complexity of factors which may influence the development of green algal mats in eutrophicated areas. However, Raffaelli et al. (1989) found a positive correlation between nutrient loads (especially nitrogen) and biomass of Enteromorpha sp. in the Ythan River (Scotland). In Königshafen Bay large quantities (in terms of abundance and biomass) of opportunistic green algae (e.g. Cladophora spp., Chaetomorpha sutoria, Enteromorpha spp. and Ulva spp.) have occurred regularly on muddy and sandy tidal flats since 1979 (Reise, 1983; Schories, 1995a), covering sediments and seagrass beds (Zostera marina and Zostera noltii) as thick mats (Fig. 2). However, maximum standing crop of these green algae has been extremely variable over the years (Reise, unpubl. data), making it almost impossible to predict their abundance and/or distribution in Königshafen Bay. Nevertheless, our investigations (in concordance with Reise et al., 1994 b) suggest that, although diverse factors interact, mass development of Enteromorpha is, overall, a consequence of high nutrient availability and, as such, a man-made problem.

In contrast, the higher number of species of Enteromorpha and Ulva nowadays is probably an artifact of the taxonomic revision of these genera since Kornmann's (1952) and Kornmann \& Sahling's (1946-1958, unpublished data) work. In the 1960s and 1980s, Bliding $(1963,1968)$ and Koeman \& van den Hoek (1982 a, b; 1984) introduced substantial taxonomic changes to Enteromorpha and Ulva, elevating several subspecies to species.

The red alga Gracilaria verrucosa, which disappeared from Königshafen in the 1980s, is viewed widely as a warm-temperate species, but it frequently occurred, together with its epiphyte Callithamnion corymbosum, in the outer part of Königshafen Bay between 1870 and 1958. We do not believe that eutrophication, expressed as increased nitrogen and phosphorus concentrations in the intertidal waters of the North Frisian Wadden Sea during winter (Martens, 1989 a, b, 1992; Hickel et al., 1993), is likely to be responsible for the disappearance of Gracilaria and Callithamnion. In the Lagoon of Venice, which is much more eutrophicated than Königshafen, Gracilaria verrucosa is still an abundant member of the macroalgal flora (Sfriso et al., 1992). Indeed, some evidence exists that Gracilaria, known for its fast growth- and high nitrogen uptake rates (Ryther et al., 1981; Thomas \& Harrison, 1987), has been suppressed by a natural phenomenon.

Nevertheless, comparing the Lagoon of Venice with Königshafen in terms of macroalgal vegetation, the same long-term trends can be observed in both areas: a decrease in red algal species richness, an increase in abundance of green algal species and a tendency for an upward movement of the lower vertical vegetation depth limits (Sfriso, 1987). Further information about long-term trends in marine macroalgae of three polluted estuaries in north-east England are given by Hardy et al. (1993). 


\section{Turbidity}

Reduced transparency of the tidal waters has probably affected macroalgal distribution, especially in the subtidal zone. Submerged algae have temporarily and locally decreased in the vicinity of Königshafen Bay. The shallower vegetation depth limit in the sublittoral at present must have resulted in a remarkable loss of macroalgae between $3 \mathrm{~m}$ and $8 \mathrm{~m}$ below MHWL as was conciuded by Reise et al. (1989) after reinvestigating Hagmeier's (1941) study sites. Light limitation through water turbidity might have resulted from excessive phytoplankton blooms (e. g. Phaeocystis globosa) as a consequence of eutrophication, or from an increase in current velocity accompanied by an increase in seston concentration. The latter process is thought to have originated from the extensive coastal embankments during recent decades. Straightening of the seaward dike lines has diminished numerous previously stable sedimentation fields, thus reducing intertidal areas, speeding up current velocities, intensifying erosion processes and increasing tidal level. For instance, the constructions of the Hindenburg causeway, which has connected the island of Sylt with the mainland since 1927, and of the Rømø causeway (finished in 1949), resulted in a substantial increase of muddy flats along the structures themselves (Wohlenberg, 1953), indicating that elsewhere in the Sylt-Rømø area a substantial amount of mud must have been eroded.

Within Königshafen Bay, on the other hand, a pronounced compaction of sediment appears to have taken place over the last 50 years (Austen, 1994), but is of no importance for the vegetation depth because there are no important subtidal areas present in the inner part of the bay other than the main tidal channel.

\section{Introduction of new species}

The anthropogenic introduction of marine organisms to intertidal areas is well documented for the Frisian Wadden Sea (Reise, 1990). Its increase over recent decades is partly due to higher human mobility and trade activity at sea which facilitates the transport of species across previously existing natural boundaries in terms of space and time. Thus, the green alga Codium fragile, which invaded European coasts in the present century, but which is very scarce in the vicinity of Königshafen Bay, and the brown alga Sargassum muticum, which was first discovered in the area in March 1993 (Schories \& Albrecht, 1995) have both made their way around the world with oyster cultures and are only two examples of a series of introduced species now established in the bay. The further extension of $S$. muticum on hard substrata remains currently unpredictable. However, there is some evidence that its distribution will be restricted to the lower intertidal zone, where it might compete with the native Fucus vesiculosus f. mytili, because both species grow attached to mussel beds.

Both examples show that the ecosystem of the Wadden Sea is dynamic and flexible enough to accommodate new species, so that further changes in the macroalgal flora due to introductions from elsewhere remain possible.

\section{CONCLUSIONS}

The macroalgal flora of Königshafen and its adjacent areas has changed during the last century. The decrease of intertidal red and brown algae is obvious. If the decline of the macrophytobenthos vegetation depth is indeed attributable to eutrophication and tur- 
bidity, prospects for the persistence of rare algal species and species richness are rather dim in the adjacent subtidal areas to Königshafen Bay, because the underlying processes still continue. Also, in the short term, there is no evidence that the mass development of green algae will cease.

We conclude that, with respect to Wadden Sea monitoring projects, Königshafen Bay is an appropriate area for phycological studies because of its overall species richness and the availability of abiotic and biotic background data. It meets the requirements for a successful monitoring program (Reise, 1989).

Acknowledgements. We gratefully acknowledge the help of P. Kornmann ( $\Psi$ ) and P.-H. Sahling, who supplied us with much unpublished material. We thank K. Reise and A. R. O. Chapman for helpful comments on the manuscript. Financial support was provided by the Federal Ministries of Research and Technology (BMBF) and the Environment (UBA). This is publication no. 273 of the project 'Ecosystem Research Wadden Sea'.

\section{LITERATURE CITED}

Agger, P., 1989. Principles for the Danish biomonitoring programme. - Helgoländer Meeresunters. 43, 309-317.

Albrecht, A., 1995. Gemeinschaftsökologie von Makroalgen auf Miesmuschelbänken (Mytilus edulis L.) im Wattenmeer. Diss., Univ. Hamburg, 150pp.

Austen, I., 1992. Geologisch-sedimentologische Kartierung des Königshafens (List / Sylt). - Meyniana $44,45-52$.

Austen, I., 1994. The surficial sediments of Königshafen - variations over the past 50 years. - Helgoländer Meeresunters. 48, 163-171.

Bayerl, K.-A. \& Higelke, B., 1994. The development of northern Sylt during the latest Holocene. Helgoländer Meeresunters. 48, 145-162.

Bliding, C., 1963. A critical survey of European taxa in Ulvales. Part I: Capsosiphon, Percursaria, Blidingia, Enteromorpha. - Opera bot. Soc. bot. Lund. 8, 1-160.

Bliding, C., 1968. A critical survey of European taxa in Ulvales. Part II: Ulva, Ulvaria, Monostroma, Kornmannia. - Bot. Notiser 121, 535-629.

Buttermoore, R. E., 1977. Eutrophication of an impounded estuarine lagoon. - Mar. Pollut. Bull. 8 r 13-15.

Fong, P., Donohoe, R. M. \& Zedler, J. B., 1993. Competition with macroalgae and benthic cyanobacterial mats limits phytoplankton abundance in experimental microcosms. - Mar. Ecol. Prog. Ser. $100,97-102$.

Geertz-Hansen, O., Sand-Jensen, K., Hansen, D. F. \& Christiansen, A., 1993. Growth and grazing control of abundance of the marine macroalga Ulva lactuca L. in a eutrophic Danish estuary. Aquat. Bot. 46, 101-109.

Goor, A. C. J. van, 1921. Die Zostera-Assoziation der holländischen Meeresalgen. - Recl Trav. bot. neerl. 18, 103-123.

Hagmeier, A., 1941. Die intensive Nutzung des nordfriesischen Wattenmeeres durch Austern- und Muschelkultur. - Z. Fisch. 39, 105-161.

Hardy, F. G., Evans, S. M. \& Tremayne, M. A., 1993. Long-term changes in the marine macroalgae of three polluted estuaries in north-east England. - J. exp. mar. Biol. Ecol. 172, 81-92.

Hartog, C. den, 1994. Suffocation of a littoral Zostera bed by Enteromorpha radiata. - Aquat. Bot. 47, 21-28.

Hickel, W., Mangelsdorf, P. \& Berg, J., 1993. The human impact in the German Bight: Eutrophication during three decades (1962-1991). - Helgoländer Meeresunters. 47, 243-263.

Hoek, C. van den, 1963. Revision of the European species of Cladophora. Brill, Leiden, 248pp.

Jonge, V. de \& Peletier, H., 1992. The changing green's alternative. - Wadden Sea Newsl. 2, 27-29.

Koeman, R. P. T. \& Hoek, C. van den, 1982a. The taxonomy of Enteromorpha Link, 1820, (Chlorophyceae) in the Netherlands. The section Enteromorpha. - Arch. Hydrobiol. 63, 279-330.

Koeman, R. P. T. \& Hoek, C. van den, 1982b. The taxonomy of Enteromorpha Link, 1820, (Chlorophyceae) in the Netherlands. The section Proliferae. - Cryptogamie Algol. 3, 37-70. 
Koeman, R. P. T. \& Hoek, C. van den, 1984. The taxonomy of Enteromorpha Link, 1820 (Chlorophyceae) in the Netherlands. The sections Flexuosae and Clathratae, and an addition to the section Proliferae. - Cryptogamie Algol. 5, 21-61.

Kolbe, K., Kaminski, E., Michaelis, H., Obert, B. \& Rahmel, J., 1994. Macroalgal mass development in the Wadden Sea: first experiences with a monitoring system. - Helgoländer Meeresunters. 49, 519-528.

Kornmann, P., 1952. Die Algenvegetation von List auf Sylt. - Helgoländer wiss. Meeresunters. 4, 55-61.

Kornmann, P., 1953. Der Formenkreis von Acinetospora crinita (Carm.) nov. comb. - Helgoländer wiss. Meeresunters. 4, 205-224.

Kornmann, P., 1956. Zur Morphologie und Entwicklung von Percusaria percursa. - Helgoländer wiss. Meeresunters. 5, 259-272.

Kornmann, P., 1959. Die heterogene Gattung Gomontia. I. Der sporangiale Anteil, Codiolum polyrhizum. - Helgoländer wiss. Meeresunters. 6, 229-238.

Kornmann, P., 1960. Von Conchocelis zu Porphyra. - Helgoländer wiss. Meeresunters. 7, 189-193.

Kornmann, P., 1972. Ein Beitrag zur Taxonomie der Gattung Chaetomorpha (Cladophorales, Chlorophyta). - Helgoländer wiss. Meeresunters, 23, 1-31.

Kornmann, P. \& Sahling, P.-H., 1991. The Porphyra species of Helgoland (Bangiales, Rhodophyta).Helgoländer Meeresunters. 45, 1-38.

Kornmann, P. \& Sahling, P.-H., 1994. Meeresalgen von Helgoland: Zweite Ergänzung [Marine algae of Helgoland: second supplement] - Helgoländer Meeresunters. 48, 365-406.

Kuckuck, P., 1897. Beiträge zur Kenntnis der Meeresalgen, 1-4. - Wiss. Meeresunters. (Abt. Helgoland) 2, 329-370.

Kuckuck, P., 1900. Beiträge zur Kenntnis der Meeresalgen, 5-9. - Wiss. Meeresunters. (Abt. Helgoland) $3,13-82$.

Kuckuck, P., 1902. Beiträge zur Kenntnis der Meeresalgen, 10-12. - Wiss. Meeresunters. (Abt. Helgoland) 5, 117-228.

Lotze, H., 1994. Phänologische und ökophysiologische Untersuchungen an Grünalgen im Wattenmeer. Dipl.-Arb., Univ. Kiel, 78 pp.

Magnus, P., 1874. Die botanischen Ergebnisse der Nordseefahrt vom 21. Juli bis 9. Sept. 1872. - Ber. Kommn. Unters. dt. Meere, 2, 60-80.

Martens, P., 1989a. On trends in nutrient concentration in the northern Wadden Sea of Sylt. - Helgoländer Meeresunters. 43, 489-499.

Martens, P., 1989b. Inorganic phytoplankton nutrients in the Wadden Sea areas of Schleswig-Holstein. I. Dissolved anorganic nitrogen. - Helgoländer Meeresunters. 43, 77-85.

Martens, P., 1992. Inorganic phytoplankton nutrients in the Wadden Sea areas of Schleswig-Holstein. II. Dissolved ortho-phosphate and reactive silicate with comments on the zooplankton. Helgoländer Meeresunters. 46, 103-115.

Mollenhauer, D. \& Lüning, K., 1988. Helgoland und die Erforschung der marinen Benthosalgen. Helgoländer Meeresunters. 42, 385-425.

Montgomery, H. A. C. \& Soulsby, P. G., 1981. Effects of eutrophication on the intertidal ecology of Langstone Harbour U. K. and proposed control measures. - Prog. Wat. Tech. 13, 287-294.

Nielsen, R., Kristiansen, A., Mathiesen, H. \& Mathiesen, L., 1995. Distributional index of the benthic macroalgae in the Baltic Sea area. - Acta bot. fenn. 155, 1-51.

Nienburg, W., 1927. Zur Ökologie der Flora des Wattenmeeres. 1. Teil. Der Königshafen bei List auf Sylt. - Wiss. Meeresunters. (Abt. Kiel) 20, 146-196.

Pankow, H., 1971. Algenflora der Ostsee. İ. Benthos. Fischer, Jena, 419 pp.

Pankow, H., 1990. Ostsee-Algenflora. Fischer, Jena, 648 pp.

Piriou, J. \& Menesguen, A., 1992. Environmental factors controlling Ulva blooms in Brittany (France). In: Marine eutrophication and population dynamics. Ed. by G. Colombo, I. Ferrari, V. Ceccerelli \& R. Rossi. Olsen \& Olsen, Fredensborg, 111-115.

Raffaelli, D., Hull, S. \& Milne, H., 1989. Long-term changes in nutrients, weed mats and shorebirds in an estuarine system. - Cah. Biol. mar. 30, 259-270.

Reinbold, T., 1892. Beiträge zur Kenntnis der Algenvegetation des östlichen Theiles der Nordsee. Schr. naturw. Ver. Schlesw.-Holst. 9, 219-228. 
Reinke, J., 1889a. Atlas deutscher Meeresalgen. Parey, Berlin, 1, 1-34.

Reinke, J., 1889b. Algenflora der westlichen Ostsee deutschen Anteils. - Ber. Kommn wiss. Unters. dt. Meere 6, 1-101.

Reinke, J., 1889c. Notiz über die Vegetationsverhältnisse in der Deutschen Bucht der Nordsee. - Ber. dt. bot. Ges. 7, 367-369.

Reinke, J., 1892. Atlas deutscher Meeresalgen. Parey, Berlin, 2, 35-70.

Reise, K., 1983. Sewage, green algal mats anchored by lugworms, and the effects on turbellaria and small polychaeta. - Helgoländer Meeresunters. 36, 151-162.

Reise, K., 1985. Tidal flat ecology. Springer, Heidelberg, 191 pp.

Reise, K., 1989. Monitoring the Wadden Sea - an introduction. - Helgoländer Meeresunters. 43, 259-262.

Reise, K., 1994. Changing life under the tides of the Wadden Sea during the 20th century. - Ophelia (Suppl.) $6,117-125$.

Reise, K. \& Siebert, I., 1994. Mass occurrence of green algae in the German Wadden Sea. - Dt. hydrogr. Z. (Suppl.) 1, 171-180.

Reise, K., Herre, E. \& Sturm, M., 1989. Historical changes in the benthos of the Wadden Sea around the island of Sylt in the North Sea. - Helgoländer Meeresunters. 43, 417-433.

Reise, K., Herre, E. \& Sturm, M., 1994a. Biomass and abundance of macrofauna in intertidal sediments of Königshafen in the northern Wadden Sea. - Helgoländer Meeresunters. 48, 201-215.

Reise, K., Kolbe, K. \& Jonge, V. de, 1994b. Makroalgen und Seegrasbestände im Wattenmeer. In: Warnsignale aus dem Wattenmeer. Ed. by J. L. Lozan, E. Rachor, K. Reise, H. von Westernhagen \& W. Lenz. Blackwell, Berlin, 90-100.

Ryther, J. H., Corwin, N., Deusk, T. A. \& Williams, C. D., 1981. Nitrogen uptake and storage by the red alga Gracilaria tikvahiae. - Aquaculture 26, 107-115.

Sawyer, N., 1965. The sea lettuce problem in Boston harbour. - J. Wat. Pollut. Contr. Fed. 37, 1122-1133.

Schories, D., 1995a. Populationsökologie und Massenentwicklung von Enteromorpha spp. (Chlorophyta) im Sylter Wattenmeer. - Ber. Inst. Meeresk., Kiel 271, 1-145.

Schories, D., 1995b. Sporulation of Enteromorpha spp. (Chlorophyta) and overwintering of spores in sediments of the Wadden Sea, island Sylt, North Sea. - Neth. J. aquat. Ecol. 29, 341-347.

Schories, D. \& Albrecht, A., 1995. Sargassum muticum - Der japanische Beerentang im deutschen Wattenmeer. - Natur Mus., Frankf. 125, 92-98.

Schories, D. \& Reise, K., 1993. Germination and anchorage of Enteromorpha spp. in sediments of the Wadden Sea. - Helgoländer Meeresunters. 47, 275-285.

Sfriso, A., 1987. Flora and vertical distribution of macroalgae in the Lagoon of Venice: A comparison with previous studies. - G. bot. ital. 121, 69-85.

Sfriso, A., Marcomini, A. \& Pavoni, B., 1987. Relationships between macroalgal biomass and nutrient concentrations in a hypertrophic area of the Venice Lagoon. - Mar. environ. Res. 22, 297-312.

Sfriso, A., Pavoni, B., Marcomini, A. \& Orio, A. A., 1992. Macroalgae, nutrient cycles, and pollutants in the Lagoon of Venice. - Estuaries 15, 517-528.

Söderström, J., 1963. Studies in Cladophora. - Bot. gothoburg. 1, 1-147.

Steentoft, M., Irvine, L. M. \& Farnham, W. F., 1995. Two terete species of Gracilaria and Gracilariopsis (Gracilariales, Rhodophyta) in Britain. - Phycologia 34, 113-127.

Thomas, T. E. \& Harrison, P. J., 1987. Rapid ammonium uptake and nitrogen interactions in five intertidal seaweeds grown under field conditions. - J. exp. mar. Biol. Ecol. 107, 1-8.

Townsend, C. \& Lawson, G. W., 1972. Preliminary results on factors causing zonation in Enteromorpha using a tide simulating apparatus. - J. exp. mar. Biol. Ecol. 8, 265-276.

Wilhelmsen, U. \& Reise, K., 1994. Grazing on green algae by the periwinkle Littorina littorea in the Wadden Sea. - Helgoländer Meeresunters. 48, 233-242.

Wohlenberg, E., 1935. Beobachtungen über das Seegras, Zostera marina, und seine Erkrankung im nordfriesischen Wattenmeer. - Nordelbingen 11, 1-19.

Wohlenberg, E., 1937. Die Wattenmeer-Lebensgemeinschaften im Königshafen von Sylt. - Helgoländer wiss. Meeresunters. 1, 1-92.

Wohlenberg, E., 1953. Sinkstoff, Sediment und Anwachs am Hindenburgdamm. - Küste 2, 33-94 